\title{
Carbon sequestration in soil following afforestation of former agricultural land in the Czech Republic
}

\author{
Jan Cukor*, Zdeněk Vacek, Rostislav Linda, Lukáš Bílek \\ Czech University of Life Sciences Prague, Faculty of Forestry and Wood Sciences, Kamýcká 129, CZ - 16521 Prague 6 - Suchdol, \\ Czech Republic
}

\section{Abstract}

Soil organic carbon (SOC) is a great component of the global carbon cycle and plays significant role in terms of climatic changes and agricultural land-use. An important management concern is the extent of SOC stocks sequestration when farmland is converted to forest stands. We have reviewed the literature about changes in SOC stock in relation to altitude and stand age and sought differences between former agricultural land and origin forest stands. Accumulation of SOC was monitored in 17 examples (41 samples) in 9 locations across the all Czech Republic with focus on the main tree species Norway spruce (Picea abies [L.] Karst.). Results showed a significant increase of SOC stock in an afforested farmland with increasing stand age. Another factor was the altitude. With increasing altitude, the carbon stock in our model gradually decreased. From the data analyzed comparing forest stand and former agricultural land, similar carbon sequestration was documented for both variants with higher SOC for forest stands. However, other conditions affecting SOC stock should be taken into consideration, especially silvicultural management, topography, disturbances, soil properties and cultivation. The general tendencies of SOC changes at the investigated sites are comparable to those in other studies across the Europe.
\end{abstract}

Key words: carbon storage; soil organic matter; abandoned farmland; land-use change; temperate forest soil

Editor: Bohdan Konôpka

\section{Introduction}

Forestry is characterized by long-term production cycles (Cienciala et al. 2008) and multifunctionality of forest ecosystems. Forest provides people with a wide range of resources and ecosystem services (Kindler 2016). These benefits are often subdivided into three groups ecological forest functions, socio-cultural benefits and forest products, especially wood products (Stenger et al. 2009). Ecological forest function comprise prevention of soil erosion, local climate regulation (de Groot et al. 2002; Vacek et al. 2003), and - gaining in importance nowadays - carbon sequestration (Vanguelova et al. 2013; Grüneberg et al. 2014; Pukkala 2014; Ahmed et al. 2016). Forest ecosystems' potential to accumulate SOC and, therefore, mitigate climate change attracts an increasing number of researchers in the environmental field (Cienciala et al. 2008). Forest soils hold an important position in evaluation of forest ecosystems dynamics in anthropogenically influenced areas (Furst et al. 2007). Carbon sequestration is also a political issue with global significance, embodied in international agreements, such as the Climate Convention (UNFCCC - United Nations'
Convention on Climate Change) and the Kyoto Protocol (Cienciala et al. 2008; Lugato \& Berti 2008; Grüneberg et al. 2014). The role of forests in the global carbon cycle is thus carbon sequestration from the atmosphere through photosynthesis. During this process, carbon is released into the atmosphere again, or its part is bound to the tree biomass and soil organic matter (SOM) (Post \& Kwon 2000).

Overall, forests represent a very important carbon repository (Vacek et al. 2013; Holubík et al. 2014; Fujisaki et al. 2015), with its greater part bound in the forest soil (Guo \& Gifford 2002). It is estimated that approximately 30 to $50 \%$ of total carbon content in forests is located in soils (Dixon et al. 1994; Paul et al. 2002; Pan et al. 2011; Wiesmeier et al. 2013; Grüneberg et al. 2014). The amount of accumulated carbon and its distribution in the soil profile is influenced by individual tree species (Augusto et al. 2015; Andivia et al. 2016). Carbon accumulation is also significantly affected by the type of economic land use (Blanco-Canqui et al. 2014; Wiesmeier et al. 2015; Fujisaki et al. 2015); in some cases, cultivation of forest soils can even reduce SOC (Murty et al. 2002). Afforestation of agricultural land can - together with 
other benefits such as higher timber mass production or higher biodiversity (Podrázský et al. 2011; Woziwoda et al. 2014; Vacek et al. 2016; Cukor et al. 2017a; Vacek et al. 2017) - significantly increase the carbon content bound in the ecosystem (Kacálek et al. 2011), which in turn contributes to reducing carbon concentrations in the atmosphere (Novara et al. 2014; Woziwoda et al. 2014).

The potential of abandoned agricultural land and the total of land suitable for afforestation is quite considerable, from a global perspective. Over the world, there are approximately $385-472$ million hectares of abandoned farmland suitable to be afforested with fast-growing tree species (Campbell et al. 2008). Similarly in Europe, where agricultural land is assumed to be partially turned into forest land as well (Rounsevell et al. 2006; Stoate et al. 2009; Ruskule et al. 2016). An increase in forest land area and a decrease in farmland area has been observed in Europe since the early $19^{\text {th }}$ century (Wulf 2004; Prishchepov 2012); currently, an area of approximately 12 16 million hectares (FAO 2008; Campbell et al. 2008) is considered to be afforested on this continent. The area of agricultural and non-forest land suitable for afforestation can be illustrated on the example of the Czech Republic. The exact size of land suitable for afforestation depends on the criteria of evaluation; in most cases, the estimates range from 50,000 to 500,000 hectares (Podrázský \& Štěpáník 2002; Vopravil et al. 2015).

Areas of the land suitable for afforestation are vast, therefore it is important to pay attention not only to production capabilities of various tree species growing on non-forest land, but also to other factors, including accumulation of carbon. In the present study carbon sequestration is studied in the soil organic matter in stands of most common tree species growing in the Czech Republic (Norway spruce /Picea abies [L.] Karst./, European beech /Fagus sylvatica L./, English oak/Quercus robur L./) and tree species with generally high wood production (European larch/Larix decidua Mill./, Douglas fir/Pseudotsuga menziesii Engelm./). The objective of our study is to investigate how carbon content in the surface humus changes within the altitudinal gradient, species composition (coniferous $x$ deciduous) and the age of the stand on the permanent forest land in comparison to afforested farmland. The development of carbon content in upper humus layer in relation to above-mentioned variables is based on studies already published.

\section{Methods}

Determination of carbon content in the surface humus of various tree species was based on all previously published data available for the Czech Republic. In the past, studies dealing with raw humus accumulation on agricultural land and on permanent forest land were elaborated at the Department of Silviculture of the Faculty of Forestry and Wood Sciences of the Czech University of Life Sciences in Prague, at the Forestry and Game Management Research Institute, and at the Forest Ecology Institute of the Faculty of Forestry and Wood Technology of Mendel University in Brno. Distribution of particular locations within the Czech Republic is shown in Fig. 1.

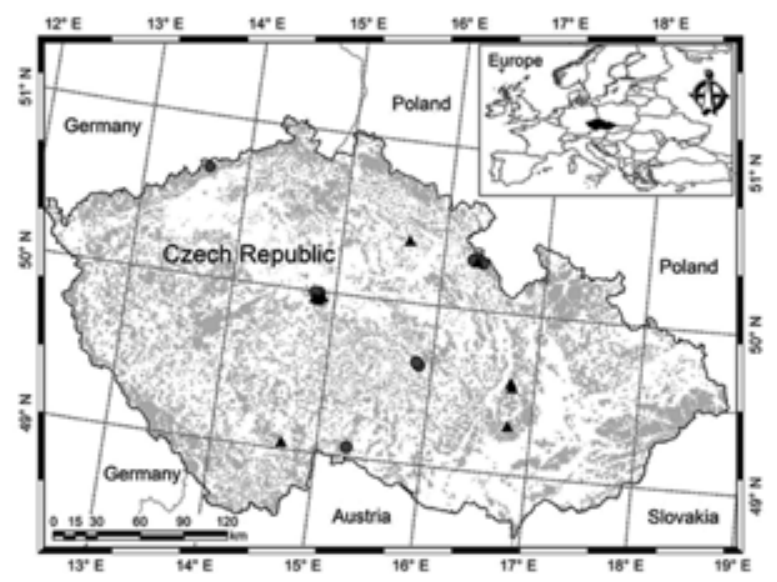

Fig. 1. Location of research plots on former agricultural land (gray circles) and in forest stands (black triangles).

The methodology of holorganic humus collection is always described in the particular work, cited in our paper. Calculation of carbon in tonnes per hectare was based on total humus in accordance with the following equation which calculates the carbon content from the total humus in per cents. The resulting carbon accumulation was based on the sum for particular layers of the humus in L, F and H horizons (Š́ly 1978).

$$
\sum_{(L, F, H)} \frac{h_{(t / h a)}}{100} * \frac{h_{(\%)}}{1.724}
$$

$h_{(t / h a)} \quad$ - total upper-layer humus in tonnes per hectare

$h_{(\%)}-$ total humus in \%

1.724 - coefficient of $\mathrm{C}$ content converted to total humus (Šály 1978).

Conversion to the total carbon accumulation and description of particular localities are presented in Table 1 (afforested agricultural land) and in Table 2 (permanent forest land).

\section{Statistical evaluation}

The location, stand type (broadleaved vs. coniferous), age, altitude (m AMSL), land use (former agricultural land/forest) and relevant soil carbon content data were available for statistical analyses. Tree species were separated into two groups (coniferous and broadleaved) for obtaining more records in each of this group. For modelling of soil carbon content $\left(\mathrm{t} \mathrm{ha}^{-1}\right)$, generalized linear mixed effect model (GLMM) was selected as the first approach. All computations were performed in R software (R Core Team 2016). 
Table 1. Carbon accumulation on former agricultural land.

\begin{tabular}{|c|c|c|c|c|c|c|}
\hline Locality & Tree species & Age [years] & Altitude [meters] & Forest site type & $\begin{array}{c}\text { Carbon accumulation } \\
{\left[\mathrm{t} \mathrm{ha}^{-1}\right]}\end{array}$ & Authors \\
\hline \multirow{3}{*}{ Kostelec nad Černými lesy } & Pine & 39 & & & 11.11 & \multirow{3}{*}{ Podrázský et al. 2010} \\
\hline & Spruce & 39 & 430 & 4Q1 & 12.03 & \\
\hline & Dg fir & 39 & & & 10.3 & \\
\hline \multirow{2}{*}{ Deštné v Orlických horách } & Spruce & 57 & 860 & & 3.43 & \multirow{2}{*}{ Hatlapatková \& Podrázský 2011} \\
\hline & Beech & 40 & 800 & $6 \mathrm{~K}$ & 1.3 & \\
\hline \multirow{2}{*}{ Fláje } & Spruce & 18 & 800 & & 9.43 & \multirow{2}{*}{ Podrázský 2008} \\
\hline & Larch & 12 & 800 & $8 \mathrm{~K} 1$ & 2.83 & \\
\hline \multirow{2}{*}{ Bystré v Orlických horách } & Spruce & 12 & 517 & $4 \mathrm{~K}$ & 5.54 & \multirow{4}{*}{ Kacálek et al. 2010} \\
\hline & Beech & 12 & 517 & $4 \mathrm{~K}$ & 5.83 & \\
\hline \multirow{2}{*}{ Krahulec v Orlických horách } & Birch & 12 & 590 & $4 \mathrm{~K}$ & 2.37 & \\
\hline & Spruce & 50 & 600 & $4 \mathrm{~K}$ & 17.67 & \\
\hline \multirow{4}{*}{ Český Rudolec } & Red oak & & & & 3.43 & \multirow{4}{*}{ Podrázský \& Ulbrichová 2004} \\
\hline & Birch & & & & 4.19 & \\
\hline & Spruce & $28-37$ & $600-630$ & $5 \mathrm{~K} 1$ & 10.93 & \\
\hline & Larch & & & & 14.7 & \\
\hline \multirow{3}{*}{ Krucemburk } & Spruce & 48 & \multirow{3}{*}{$610-640$} & $6 \mathrm{P} 1$ & 11.78 & \multirow{3}{*}{ Podrázský et al. 2011} \\
\hline & Spruce & 53 & & & 15.38 & \\
\hline & Larch & 52 & & 601 & 18.23 & \\
\hline Krahulec v Orlických horách & Spruce & 100 & 600 & $4 \mathrm{~K}$ & 47.82 & Bartoš et al. 2014 \\
\hline
\end{tabular}

Note: Forest site type is classified by the Czech forest ecosystem classification (Viewegh et al. 2003). Explanatory see Table 2.

Table 2. Data for carbon accumulation on forest soil.

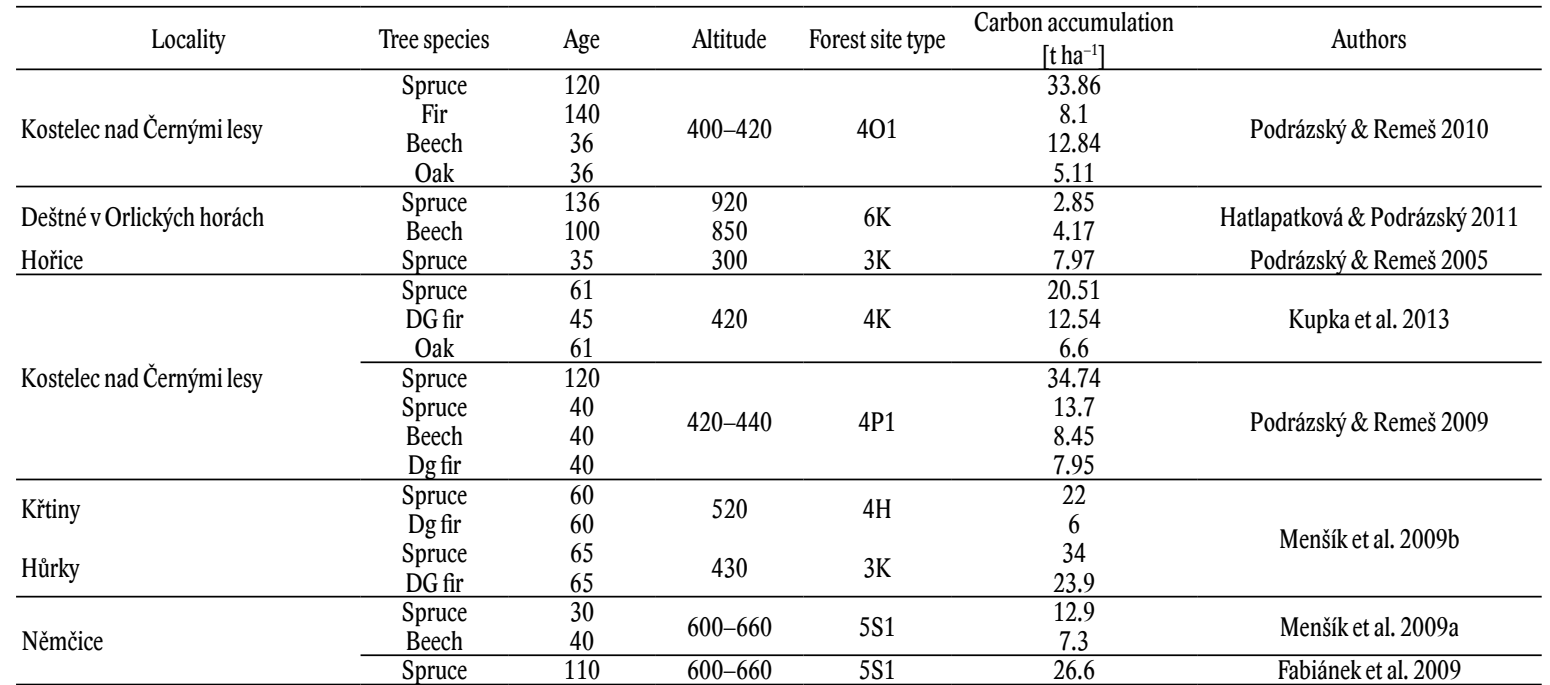

Note: Forest site type: 6P - Piceeto-Abietum variohumidum acidophilum, 60 - Piceeto-Abietum variohumidum mesotrophicum, 4Q - Querceto-Abietum variohumidum oligotrophicum, $6 \mathrm{~K}$ Piceeto-Fagetum acidophilum, $8 \mathrm{~K}$ - Piceetum acidophilum, $5 \mathrm{~K}$ - Abieto-Fagetum acidophilum, 40 - Querceto-Abietum variohumidum mesotrophicum, 4P - Querceto-Abietum variohumidum acidophilum, 4H - Fagetum illimerosum trophicum, 3K - Querceto-Fagetum acidophilum, 5S - Abieto-Fagetum mesotrophicum (Viewegh et al. 2003).

The soil carbon content data were fitted with gamma distribution via R package MASS (Venables \& Ripley 2002), while goodness of fit were subsequently tested by Kolmogorov-Smirnov test.

The full model (GLMM) was constructed as follows (notation from R software):

Carbon $\sim$ Land Use + Altitude + Age + Stand type + (1|Location)

The carbon content data were identified as random selection from gamma distribution with parameters $\alpha=1.83$ and $\beta=0.14$. The goodness of fit was tested by Kolmogorov-Smirnov test $(\mathrm{p}=0.99)$.

The sampling location was identified as random effects, while all other effect were considered fixed. Computations of GLMM were performed via R package lme4 (Bates et al. 2015).

At first, effect of land use was tested via likelihoodratio test (model with land use parameter vs. model without land use parameter). Secondly, the effect of location was evaluated. Thirdly, further models (simplified, with non-significant or unreliable factors due to data insufficiency omitted in comparison to full model) were constructed - separate models (generalized linear model GLM) for these predictors were computed.

The dependence of soil carbon content on the most significant factors was graphically represented. All hypotheses were tested at $\alpha=0.05$.

Unconstrained principal component analysis (PCA) in the Canoco 5 program (Microcomputer Power) was used to analyze relationships among SOC, stand age, altitude, climatic factors (mean temperature and precipitation), site humidity and nutrients (transformed from Czech forest ecosystem classification), ecological groups, tree species and land use (forest stand, afforested farmland) in order to reveal similarity of 41 records. Data were log-transformed, centered and standardized during the analysis. The results of the PCA analysis were visualized in the form of an ordination diagram. 


\section{Results}

Testing for significance of land use showed non-significant results $(p=0.97)$ and this parameter was therefore omitted. The random effect of location showed relatively low variance (8.1E-4) and due to relatively low number of records for some locations was not considered in further analyses.

The testing for significance of effect of tree type was evaluated by likelihood-ratio test $(p=0.0015)$, while coniferous forests showed significantly higher amount of soil organic carbon. In general, there was ca. 1.66 times higher carbon accumulation in coniferous stands compared to stands of broadleaved tree species. For further details about average carbon content depending on stand type see Fig. 2.

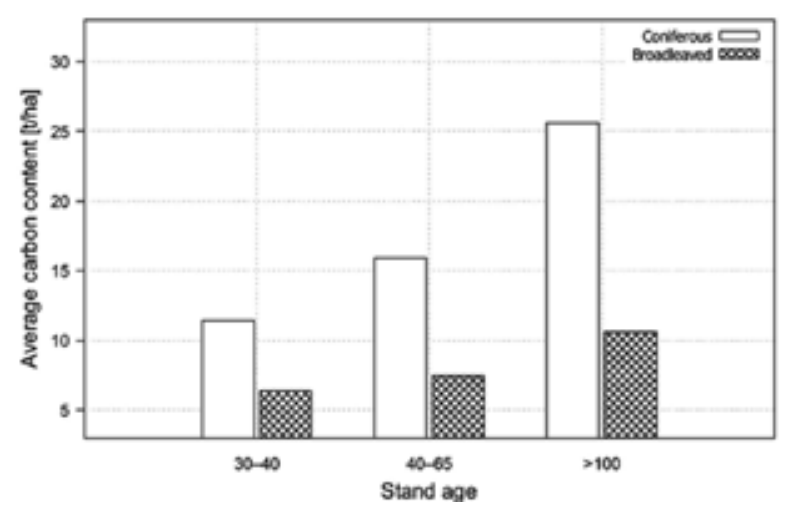

Fig. 2. Average carbon content in coniferous and broadleaved stands depending on its age (years). Coniferous forests showed significantly higher amount of soil organic carbon content $(p=0.0015)$.

The likelihood-ratio tests showed significant results for both predictors ( $p=0.02$ for altitude and $p=0.001$ for stand age). Representation of model - see Fig. 3.

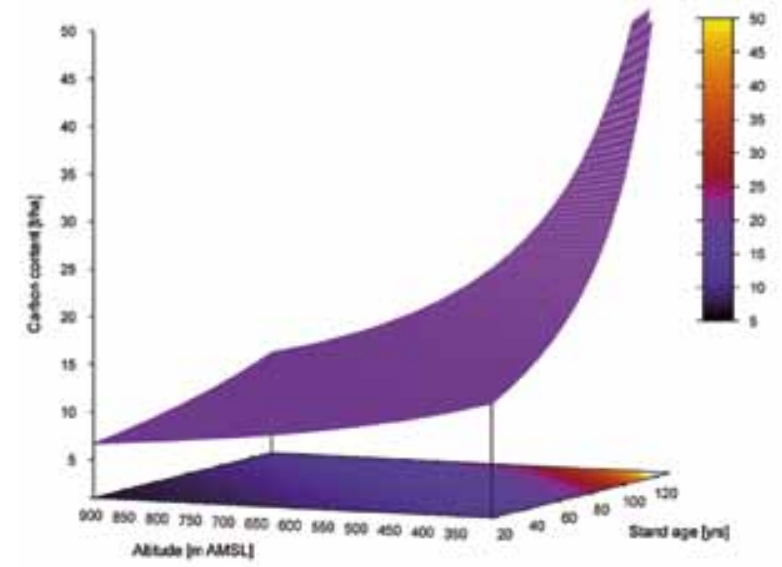

Fig. 3. Model for response of carbon content to altitude and the age of the stand. The "heatmap" at the base of the plot shows projection of estimated function.

The accuracy of the model is depicted by Fig. 4 - histogram of differences of recorded data from suggested model. The accuracy was evaluated for all selected tree species and separately for Norway spruce.

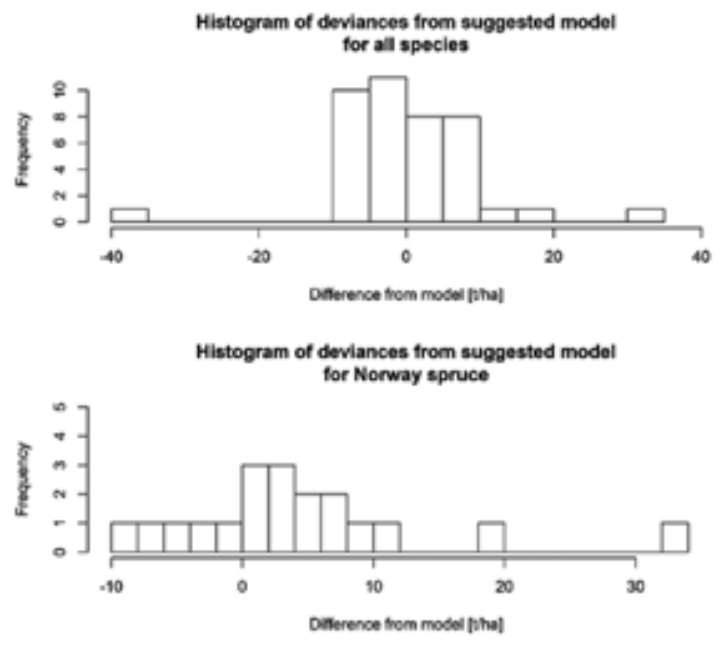

Fig. 4. Histogram of differences of data from suggested model. The accuracy was evaluated for all available records and separately for Norway spruce.

The relationships between SOC, site parameters, climate and tree species are presented in Fig. 5 by the PCA analysis. The first ordination axis explained $45.9 \%$ of variability in the data, the first two axes together $70.5 \%$ and the first four axes together explained $94.1 \%$. The first $\mathrm{x}$-axis represented the SOC stock and mean temperature with altitude and sum of precipitation. The second y-axis represented site parameters (humidity and content of nutrients). SOC was positively correlated with stand age and temperature, while these parameters were negatively correlated with altitude and precipitation. Site humidity and richness had low impact on content of carbon. Remarkable differences were observed among ecological groups (especially for Acidophilum series in terms of carbon), as marks of each record are relatively distant from one another whereas marks for forest stand and afforested agricultural land were fairly close together in the diagram. Tree species were significantly different from one another, but higher SOC stock were typical for coniferous (left part of diagram).

\section{Discussion}

The most significant factor that distinguishes agricultural land from permanent forest habitats is the null occurrence of upper-layer humus (Torreano 2004). After afforestation of the agricultural soil, a considerable part of the accumulated carbon is concentrated in the upper layers, gradually formed by forest litter; its formation and accumulation is noticeable already in young stands (Kacálek et al. 2011). In the phase immediately following the afforestation of agricultural land, there is a slight decrease in soil organic carbon. In the years to come, 


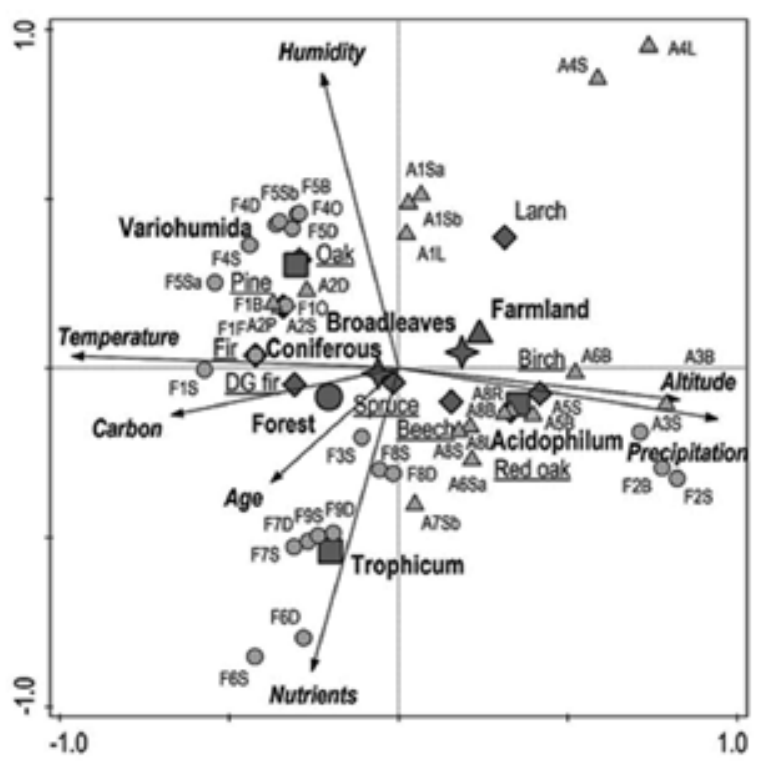

Fig. 5. Ordination diagram showing results of the PCA analysis of relationships among SOC (Carbon), stand age, altitude, climatic factors (mean temperature and sum of precipitation), site humidity and nutrients/richness (transformed from Czech forest ecosystem classification), ecological groups (Trophicum nutrient-rich - mesotrophic, Acidophilum acidic oligotrophic, Variohumida gleyed - strongly fluctuating water tables) tree species (Coniferous, Broadleaves; Spruce, Beech, Birch, Larch, Fir, DG fir, Red oak, Oak, Pine) and land use (Forest forest stand, Farmland afforested agricultural land); Codes indicate: $\bullet$ forest stand, $\boldsymbol{\wedge}$ afforested farmland; $\bullet$ tree species, $\mathbf{-}$ ecological groups.

its content is only increasing, and, subsequently, the growth of SOC on afforested agricultural land is gradually documented with increasing age of forest stand and thus with increasing accumulation of upper-layer humus (Laganière et al. 2009; Segura et al. 2016).

This trend of an increasing content of accumulated carbon with increasing age has also been confirmed by our model, which describes rising carbon content in stands up to the approximate age of 120 years. As no statistically significant differences for forest and afforested agricultural land were found, the processed data showed comparable carbon sequestration for both land uses. However PCA analysis suggests, that there is a higher SOC content on the forest soils; this results can be caused by lower age of examined stands on farmland.

Another factor that significantly affected the content of carbon in the upper-layer humus was the altitude. In accordance with our model, the carbon content declined gradually with the rising altitude. Different results were found in Germany, where a higher carbon stock deposited in upper-layer humus at higher elevations and alpine sites where thick organic layers are common (Wiesmeier et al. 2013; Grüneberg et al. 2014). Nevertheless, these results are from alpine areas, where generally higher hummus accumulation occurs because of extreme cli- matic and site conditions. This results were not included in this study, examined gradient was between 300 to 920 meters above sea level.

However, from the statistical analysis, there is evident, that coniferous tree species accumulate more upper-layer humus (Schulp et al. 2008; Wiesmeier et al. 2013; Grüneberg et al. 2014) and that is why they often have a substantial content of accumulated carbon (Menšík et al. 2009a; Podrázský \& Remeš 2010; Kupka et al. 2013). On the other hand, this well documented difference between coniferous and deciduous tree species has in our study a lower importance compared to significant influence of site conditions (Augusto et al. 2003; Holubík et al. 2014).

Other conditions that may affect the accumulated carbon content in the upper-layer humus are: different forest management, previous land use, stand characteristics, pre-planting disturbance, soil clay content, thinning, fertilization, liming, forest fires and, to some extent, the climatic zone (Lal 2005; Schulp et al. 2008; Laganière et al. 2009; Vacet et al. 2009, 2010; Matějka et al. 2010; Blanco-Canqui et al. 2014; Grüneberg et al. 2014; Segura et al. 2016). These circumstances, however, were not taken into account in our generalized model, which is based on data already published, as we lack sufficient data for the Czech Republic. Nonetheless it was shown that afforestation of agricultural land brings, among other benefits at local scale, an increase in the carbon content in units to tens of tonnes per hectare, which can result in an important effect on the global $\mathrm{C}$ budget if sufficient agricultural land is converted (Paul et al. 2002). That is why afforestation of agricultural land not only on sites suitable for forest trees but also in less favourable localities will gain on importance as a measure improving soil conditions. Here, planting can be supported by various types of fertilization and other measures aimed at better growth and the survival rate of seedlings (Podrázský et al. 2003; Kuneš et al. 2009; Tužinský et al. 2015; Cukor et al. 2017b).

\section{Conclusions}

The paper confirms the hypothesis about the influence of altitude and stand age on the SOC stock in the studied localities in the Czech Republic. However, relatively limited and variable number of samples on the compared variants must be considered when interpreting the present results. Stand age has significant positive effect on SOC content, while carbon stock decreased with increasing altitude. Difference between forest stands and afforested farmland, such as conifers and broadleaves was lower in the studied case (minor importance of tree species) compared to site. Considering the current knowledge about this important topic and still the lack of studies about carbon sequestration in soil following afforestation of former agricultural land, it is necessary to continue in 
research to answer all questions and ambiguities. The studies should be focused on other factors significantly influencing the carbon content in the soil, especially impact of forest management, soil cultivation, previous land use and actual climatic changes.

\section{Acknowledgments}

This study was supported by the Internal Grant Agency (project no. B03/17), Faculty of Forestry and Wood Sciences, Czech University of Life Sciences, Prague.

\section{References}

Ahmed, I. U., Smith, A. R., Jones, D. L., Godbold, D. L., 2016: Tree species identity influences the vertical distribution of labile and recalcitrant carbon in a temperate deciduous forest soil. Forest Ecology and Management, 359:352-360.

Andivia, E., Rolo, V., Jonard, M., Formanek, P., Ponette, Q., 2016:Tree species identity mediates mechanisms of top soil carbon sequestration in a Norway spruce and European beech mixed forest. Annals of Forest Science, 73:437-447.

Augusto, L., De Schrijver, A., Vesterdal, L., Smolander, A., Prescott. C., Ranger, J., 2015: Influences of evergreen gymnosperm and deciduous angiosperm tree species on the functioning of temperate and boreal forests. Biological Reviews, 90:444-466.

Bates, D., Maechler, M., Bolker, B., Walker, S., 2015: Fitting Linear Mixed-Effects Models Using lme4. Journal of Statistical Software, 67:1-48.

Bartoš, J., 2014: Biologické a ekonomické aspekty zalesňování zemědělských půd. Disertační práce, Praha, FLD ČZU v Praze, 128 p.

Blanco-Canqui, H., Lal, R., 2004: Mechanisms of carbon sequestration in soil aggregates. Critical Reviews in Plant Sciences, 23:481-504.

Campbell, J. E., Lobell, D. B., Genova, R. C., Field, C. B., 2008: The global potential of bioenergy on abandoned agriculture lands. Environmental Science \& Technology, 242:5791-5794.

Cienciala, E., Exnerová, Z., Schelhaas, M. J., 2008: Development of forest carbon stock and wood production in the Czech Republic until 2060. Annals of Forest Research, 65:603.

Cukor, J., Baláš, M., Kupka, I., Tužinský, M., 2017a:The condition of forest stands on afforested agricultural land in the Orlické hory Mts. Journal of Forest Science, 63:1-8.

Cukor, J., Linhart, L., Vacek, Z., Baláš, M., Linda, R., 2017b: The Effects of Alginite Fertilization on Selected Tree Species Seedlings Performance on Afforested Agricultural Land. Forestry Journal, 63: 48-56. de Groot, R. S., Wilson, M.A., Boumans, R. M. J., 2002: A typology for the classification, description and valuation of ecosystem functions, goods and services. Ecological Economics, 41:393-408.

Dixon, R. K., Brown, S., Houghton, R. A., Solomon, A. M., Trexler, M. C., Wisniewski, J., 1994: Carbon Pools and Flux of Global Forest Ecosystems. Science, 263:185-190.

Fabiánek, T., Menšík, L., Tomášková, I., Kulhavý, J., 2009: Effects of spruce, beech and mixed commercial stand on humus conditions of forest soils. Journal of Forest Science, 55:119-126.

Fujisaki, K., Perrin, A. S., Desjardins, T., Bernoux, M., Balbino, L. C., Brossard, M., 2015: From forest to cropland and pasture systems: a critical review of soil organic carbon stocks changes in Amazonia. Global change biology, 21:2773-2786.

FAO, 2008: Fighting food inflation through sustainable investment: grain production and export potential in CIS countries e rising food prices: causes, consequences and policy responses. Rome: Food and Agriculture Organization of the United Nations; 2008 March 10. 16 p. Sponsored by the European Bank for Reconstruction and development and the FAO.

Grüneberg, E., Ziche, D., Wellbrock, N., 2014: Organic carbon stocks and sequestration rates of forest soils in Germany. Global Change Biology, 20:2644-2662.

Guo, L. B., Gifford, R. M., 2002: Soil carbon stocks and land use change: a meta analysis. Global Change Biology, 4:345-360.

Hatlapatková, L., Podrázský, V., 2011: Obnova vrstev nadložního humusu na zalesněných zemědělských půdách. Zprávy lesnického výzkumu, 56:228-234.

Holubík, O., Podrázský, V., Vopravil, J., Khel, T., Remeš, J., 2014: Effect of agricultural lands afforestation and tree species composition on the soil reaction, total organic carbon and nitrogen content in the uppermost mineral soil profile. Soil \& Water Research, 9:192-200.

Kacálek, D., Dušek, D., Novák, J., Slodičák, M., Bartoš, J., Černohous, V., Balcar, V., 2011: Former agriculture impacts on properties of Norway spruce forest floor and soil. Forest Systems, 20:437-443.

Kacálek, D., Novák, J., Bartoš, J., Slodičák, M., Balcar, V., Černohous, V., 2010: Vlastnosti nadložního humusu a svrchní vrstvy půdy ve vztahu k druhům dřevin. Zprávy lesnického výzkumu, 55:19-25.

Kindler, E., 2016: A comparison of the concepts: Ecosystem services and forest functions to improve interdisciplinary exchange. Forest Policy and Economics, 67: 52-59.

Kuneš, I., Balcar, V., Benešová, T., Baláš, M., Zadina, J., Zahradník, D. et al., 2009: Influence of pulverized limestone and amphibolite mixture on the growth performance of Alnus incana [L.] Moench plantation on an acidified mountain site. Journal of Forest Science, 55:469-476. 
Kupka, I., Podrázský, V., Kubeček, J., 2013: Soil-forming effect of Douglas fir at lower altitudes - a case study. Journal of Forest Science, 59:345-351.

Lal, R., 2005: Forest soils and carbon sequestration. Forest Ecology and Management, 220:242-258.

Lugato, E., Berti, A., 2008: Potential carbon sequestration in a cultivated soil under different climate change scenarios: A modelling approach for evaluating promising management practices in northeast Italy. Agriculture Ecosystems \& Environment, 128:97-103.

Matějka, K., Vacek, S., Podrázský, V., 2010: Development of forest soils in the Krkonoše Mts. in the period 1980-2009. Journal of Forest Science, 56: 485-504.

Menšík, L., Fabiánek, T., Tesař, V., Kulhavý, J., 2009a: Humus conditions and stand characteristics of artificially established young stands in the process of the transformation of spruce monocultures. Journal of Forest Science, 55:215-223.

Menšík, L., Kulhavý, J., Kantor, P., Remeš, J., 2009b: Humus conditions of stands with different proportions of Douglas fir in the Hůrky Training Forest District and Krrtiny Training Forest Enterprise. Journal of Forest Science, 55:345-356.

Murty, D., Kirschbaum, M. U. F., McMurtrie, R. E., McGilvray, A., 2002: Does conversion of forest to agricultural land change soil carbon and nitrogen? a review of the literature. Global Change Biology, 8:105-123.

Novara, A., La Mantia, T., Rühl, J., Badalucco, L., Kuzyakov, Y., Gristina, L., Laudicina, V. A., 2014: Dynamics of soil organic carbon pools after agricultural abandonment. Geoderma, 235-236: 191-198.

Pan, Y. D., Birdsey, R. A., Fang, J. Y., Houghton, R., Kauppi, P. E., Kunz, W. A. et al., 2011: A Large and Persistent Carbon Sink in the World's Forests. Science, 333:988-993.

Paul, K. I., Polglase, P. J., Nyakuengama, J. G., Khanna, P.K., 2002: Change in soil carbon following afforestation. Forest Ecology and Management, 168:241-257.

Podrázský, V., Štěpaník, R., 2002: Vývoj půd na zalesněných zemědělských plochách - oblast LS Český Rudolec. Zprávy lesnického výzkumu, 47:53-56.

Podrázský, V., Remeš, J., Ulbrichová, I., 2003: Biological and chemical amelioration effects on the localities degraded bybulldozer sitepreparartion in the Ore Mts. - Czech Republic. Journalof Forest Science, 49:141147.

Podrázský, V., Ulbrichová, I., 2004: Restoration of forest soils on reforested abandoned agricultural lands. Journal of Forest Science, 50:249-255.

Podrázský, V., 2008: Tvorba povrchového humusu při zalesňování zemědělských ploch a po buldozerové přípravě v Krušných horách. Zprávy lesnického výzkumu, 53:258-263.
Podrázský, V., Remeš, J., 2009: Soil-forming effect of Grand fir (Abies grandis [Dougl. ex D. Don] Lindl.). Journal of Forest Science, 55:533-539.

Podrázský, V., Remeš, J., Hart, V., Moser, W. K., 2009: Production and humus form development in forest stands established on agricultural lands - Kostelec nad Černými lesy region. Journal of Forest Science, 55:299-305.

Podrázský, V., Remeš, J., 2010: Vliv druhové skladby lesních porostů na stav humusových forem na území ŠLP v Kostelci nad Černými Lesy. Zprávy lesnického výzkumu, 55:71-77.

Podrázský, V., Procházka, J., Remeš, J., 2011: Produkce a vývoj půdního prostředí porostů na bývalých zemědělských půdách v oblasti Českomoravské vrchoviny. Zprávy lesnického výzkumu, 56:27-35.

Podrázský, V., Remeš, J., Tauchman, P., Hart, V., 2010: Douglaska tisolistá a její funkční účinky na zalesněných zemědělských půdách. Zprávy lesnického výzkumu, 55:12-18.

Post, W. M., Kwon, K. C., 2000: Soil carbon sequestration and land-use change: processes and potential. Global Change Biology, 6:317-327.

Prishchepov, A. V., Radeloff, V. C., Baumann, M., Kuemmerle, T., Müller, D., 2012: Effects of institutional changes on land use: agricultural land abandonment during the transition from state-command to marketdriven economies in post-Soviet Eastern Europe. Environmental Research Letters, 7:13.

Pukkala, T., 2014: Does biofuel harvesting and continuous cover management increase carbon sequestration? Forest Policy and Economics, 43:41-50.

R Core Team, 2016: R: A language and environment for statistical computing. R Foundation for Statistical Computing, Vienna, Austria.

Rounsevell, M. D. A., Reginster, I., Araújo, M.B., Carter, T. R., Dendoncker, N., Ewert, F. et al., 2006: A coherent set of future land use change scenarios for Europe. Agriculture, Ecosystems and Environment 114:57-68.

Ruskule, A., Nikodemus, O., Kasparinskis, R., Prižavoite, D., Bojāre, D., Brūmelis, G., 2016: Soil - vegetation interaction in abandoned farmland within the temperate region of Europe. New Forests, 47:587-605.

Schulp, C. J. E., Nabuurs, G. J., Verburg, P. H., Waal, R. W., 2008: Effect of tree species on carbon stocks in forest floor and mineral soil and implications for soil carbon inventories. Forest Ecology and Management, 256:482-490.

Segura, C., Jiménez, M. J., Nieto, O., Navarro, F. B., Fernández-Ondoño, E., 2016: Changes in soil organic carbon over 20 years after afforestation in semiarid SE Spain. Forest Ecology and Management, 381:268-278.

Stenger, A., Harou, P., Navrud, S., 2009: Valuing environmental goods and services derived from the forests. Journal of Forest Economics, 15:1-14. 
Stoate, C., Báldi, A., Bejca, P., Boatman, N. D., Herzon, I., Doorn, A. et al., 2009: Ecological impacts of early 21st century agricultural change in Europe A review. Journal of Environmental Management, 91:22-46.

Šály, R., 1978: Pôda, základ lesnej produkcie. Bratislava, Príroda, $235 \mathrm{p}$.

Torreano, S., 2004: Soil development and properties. In: Burley, J., Evans, J., Youngquist, J. A. (ed.): Encyclopedia of Forest Sciences, Vol. 3. Oxford, Elsevier, p. 1208-1216.

Tužinský, M., Kupka, I., Podrázský, V., Prknová, H., 2015: Influence of the mineral rock alginite on survival rate and rate-growth of selected tree species on agricultural land. Journal of Forest Science, 61:399_ 405.

Vacek, S., Podrázský, V., Mikeska, M., Moser, W. K., 2003: Introskeletal erosion threat in mountain forests of the Czech Republic. Journal of Forest Science, 49:313-320.

Vacek, S., Hejcman, M., Semelová, V., Remeš, J., Podrázský, V., 2009: Effect of soil chemical properties on growth, foliation and nutrition of Norway spruce stand affected by yellowing in the Bohemian Forest Mts., Czech Republic. European Journal of Forest Research, 128:367-375.

Vacek, Z., Vacek, S., Remeš, J., Štefančík, I., Bulušek, D., Bílek, L., 2013: Struktura a modelový vývoj lesních porostů v NPR Trčkov-CHKO Orlické hory, Česká Republika. Forestry Journal, 59:248-263.

Vacek, Z., Vacek, S., Podrázský, V., Král, J., Bulušek, D., Putalová, T. et al., 2016: Structural diversity and production of alder stands on former agricultural land at high altitudes. Dendrobiology, 75:31-44.
Vacek, Z., Vacek, S., Bulušek, D., Podrázský, V., Remeš, J., Král, J., Putalová, T., 2017: Effect of fungi pathogens and climatic factors on production, biodiversity and health status of ash mountain forest. Dendrobiology, 77:161-175.

Vanguelova, E. I., Nisbet, T. R., Moffat, A. J., Broadmeadow, S., Sanders, T. G. M., Morison, J. I. L., 2013: A new evaluation of carbon stocks in British forest soils. Soil Use and Management, 29:169-181.

Venables, W. N., Ripley, B. D., 2002: Modern Applied Statistics with S. Fourth Edition. Springer, New York.

Viewegh, J., Kusbach, A., Mikeska, M., 2003: Czech forest ecosystem classification. Journal of Forest Science, 49:74-82.

Vopravil, J., Podrázský, V., Khel, T., Holubík, O., Vacek, S., 2014: Effect of afforestation of agricultural soils and tree species composition on soil physical characteristics changes. Ekologia, 33:67-80.

Wiesmeier, M., Prietzel, J., Barthold, F., Spörlein, P., Geuß, U., Hangen, E. et al., 2013: Storage and drivers of organic carbon in forest soils of southeast Germany (Bavaria) - Implications for carbon sequestration. Forest Ecology and Management, 295:162-172.

Wiesmeier, M., von Lützov, M., Spörlein, P., Geuß, U., Hangen, E., Reischl, A. et al., 2015: Land use effects on organic carbon storage in soils of Bavaria: The importance of soil types. Soil \& Tillage Research, 146:296-302.

Woziwoda, B., Parzych, A., Kopeć, D., 2014: Species diversity, biomass accumulation and carbon sequestration in the understorey of post-agricultural Scots pine forests. Silva Fennica, 48:1119.

Wulf, M., 2004: Plant species richness of afforestations with different former use and habitat continuity. Forest Ecology and Management, 195:191-204. 